DARIO BABIĆ, mag. eng. traff. ${ }^{1}$

(Corresponding author)

E-mail: dario.babic@fpz.hr

DARKO BABIĆ, Ph.D. ${ }^{1}$

E-mail: darko.babic@fpz.hr

DRAGANA MACURA, Ph.D. ${ }^{2}$

E-mail: d.macura@sf.bg.ac.rs

1 University of Zagreb,

Faculty of Transport and Traffic Sciences

Vukelićeva 4, 10000 Zagreb, Croatia

2 University of Belgrade,

Faculty of Transport and Traffic Engineering

Vojvode Stepe 305, Belgrade, Serbia
Traffic Infrastructure

Preliminary Communication

Submitted: 2 Sep. 2016

Accepted: 7 Apr. 2017

\title{
MODEL FOR PREDICTING TRAFFIC SIGNS FUNCTIONAL SERVICE LIFE - THE REPUBLIC OF CROATIA CASE STUDY
}

\begin{abstract}
Traffic signs are the basic elements of communication between the relevant road authorities and road users. They manage, regulate, inform and warn road users to ensure their safe movement throughout transport networks. Traffic signs must be timely visible to all traffic participants in all weather and traffic conditions in order to fulfil their function, which means they must have satisfactory retroreflection properties. This paper presents a research of the deterioration of traffic signs retroreflection. The aim of this article is to develop models that will effectively enable predicting the retroreflection of traffic signs and thus optimize the maintenance activities and replacement of road signs to increase road safety. The research included measurements of retroreflection of retroreflective material Classes I and II (white, red and blue colour) and Class III (red and yellow colour). Based on the collected data from the City of Zagreb (Republic of Croatia), the authors developed the models to estimate the functional service life of certain colours and materials used to make traffic signs. Considering that the average coefficient of determination for all the models is between 0.55-0.60, they present an effective tool in the traffic sign maintenance system.
\end{abstract}

\section{KEY WORDS}

traffic signs; retroreflection; traffic sign degradation; functional service life;

\section{INTRODUCTION}

Traffic signs are part of the overall traffic signalization system, that convey a message to road users by using shapes, colours, text and symbols and that are vertically placed on the traffic area. Traffic signs inform about regulations, warnings, directions, and guidance in road systems, to achieve road safety and reduce traffic accidents and fatalities [1]. To fulfil their function efficiently and therefore contribute to the increase of road safety, the signs must meet certain conditions.
They should be easily recognizable and locatable within a complex visual scene. Furthermore, they need to clearly indicate the status of the message (legal, warning or information) and convey the message efficiently, thereby minimizing visual distraction. They have to be comprehensible so that drivers can recognize the action (or choice) to be taken and located so that the driver has sufficient time to act on the message [2].

When driving in low visibility conditions (dusk, dawn, night), the drivers receive significantly less visual information in traffic which makes the perception of the surroundings, and thus the driving, considerably more challenging. The efficiency of traffic signs depends, apart from the individual characteristics of the driver, mainly on the external characteristics, among which great importance is in their legibility and optical characteristics or retroreflective properties [3]. In addition, to timely and efficiently convey the information to the drivers even in the conditions mentioned above, traffic signs must have satisfactory retroreflection properties. Retroreflection properties include the ability of a sign to reflect light from the vehicle headlights back to the driver, giving the sign an illuminated appearance [4]. This appearance is due to different retroreflective materials (sheeting) used to make the signs, which consist of tiny prisms or spheres in a weather-resistant, transparent plastic film. Generally, in Europe retroreflective materials are divided into materials of Classes I, II and III. Materials of Classes I and II use spherical or prismatic retroreflective sheeting, while materials of Class III use exclusively prismatic retroreflective sheeting. Scientific studies have proven that materials with prismatic retroreflective sheeting have significantly better performance when it comes to visibility $[5,6,7,8]$.

It is necessary to conduct periodical tests on signs in order to ensure a satisfactory level of retroreflection. 
Signs that do not meet the minimum prescribed values should be replaced with new ones to ensure timely communication between the driver and the sign. Given the number of traffic signs on the roads, it is necessary to optimize their maintenance activities. One way of optimization includes developing a mathematical model that will predict the functional service life of a traffic sign.

The aim of this research is to develop a model for predicting the traffic sign functional service life, which would help road authorities in planning the control testing of sign retroreflection and ultimately their suitable replacement, all to increase road safety.

The analysed case study is the Republic of Croatia, where the same relevant conditions exist as in other EU countries. All of the considered data have been obtained from the Croatian road network, i.e. from the City of Zagreb area.

The paper comprises five sections, the first one being the introduction, followed by Section 2 that is dedicated to a brief, relevant literature review. Section 3 presents data collection methodology, and the Results and Discussion are given in Section 4. Finally, the last section presents the Conclusions.

\section{BRIEF LITERATURE REVIEW}

The prediction of traffic sign functional service life is essential for establishing a high-quality system for traffic signalization maintenance and ensuring a satisfactory level of safety. This important feature caused numerous studies to be conducted in the last three decades aimed at understanding how the traffic sign retroreflection degrades.

One of the first studies was conducted by Black et al. in [9] where analysis of the impact of signs orientation, elevation, solar radiation levels, heating degree-days and precipitation on retroreflection degradation was done on a sample of 5,722 traffic signs. The analysis showed that age, precipitation, elevation, and temperature affected degradation and that sign direction is not a statistically significant factor. Based on the collected data, the authors developed a linear model for predicting traffic sign degradation.

The study aimed at better understanding the factors that may affect road sign retroreflection was done by Kirk et al. [10]. The study results showed that over a twelve-year period span most of the signs had retroreflection above the prescribed minimum. Also, retroreflection did not vary significantly with the age of the sign but small significant correlation between retroreflection and sign orientation was found. The authors noted that there might not have been a great enough age range of traffic signs to provide a complete picture of the retroreflection performance over time and any weathering effects.

Bischoff and Bullock [11] measured retroreflection of white, red and yellow colours on 1,341 in-service traffic signs. The study showed that service life of traffic signs with white and yellow backgrounds is 12 years and 10 years for red coloured signs due to the colour fade. Also, the collected data indicated that orientation is not a relevant factor in sign degradation.

The study aimed to analyse the performance and degradation characteristics of retroreflective sheeting materials was conducted by Wolshon et al. [12]. A total of 12 models for predicting the functional service life of traffic signs were developed. Twelve models, according to authors, were required to separate the two different sheeting types and the three different colours under wiped (cleaned) and unwiped (uncleaned) conditions. From three dependent variables (age, orientation, and the distance from the road), only age had positive correlation with the retroreflection degradation.

Rasdorf et al. [13] conducted a study analysing the expected life of 1,047 in-service traffic signs and researching relevant factors that affect the sign performance. They developed several models: linear, logarithmic, polynomial, power and exponential from which linear trend line was found to be the best fit for the degradation of retroreflection over time. Except retroreflection degradation rates over time, authors also analysed vandalism and sign damage rates.

Kipp and Fitch [14] measured 398 signs in four colours: white, red, green and yellow. The primary objective of the study was to establish a retroreflection assessment protocol for traffic signs. The study found no significant correlation between orientation and offset of traffic signs on retroreflection degradation. Similar to the results in [11], red sign retroreflection degradation was faster than other sign colours, while white had the slowest degradation rate.

In 2009, Carlson et al. [15] measured retroreflection of 1,385 traffic signs (observing four colours: white, red, green and yellow). The same as in the previous studies, their research found that sign direction was not a relevant factor in retroreflection. Using linear regression, the authors predicted functional service life of the traffic signs to be from 5 to 155 years depending on the region where they are placed. Except predicting the functional service life of traffic signs, the study also evaluated the dynamic or mobile retroreflection measurement system which enables retroreflection readings from a moving vehicle. The authors concluded that the mobile system is not accurate enough and for that reason not applicable for traffic signs retroreflection evaluation.

Pike and Carlson [16] conducted a study to determine the functional service life of different materials used to produce traffic signs. The authors observed 525 in-service signs with manufacturing date ranging from 1983 to 2012. The authors developed a linear model for each class and colour of material. The shortcoming of the study is the poor accuracy of the models; the best coefficient of determination was $R^{2} 0.4436$. 
Preston et al. [17] conducted a similar study, with results that are consistent with the previous studies.

Table 1 presents a summary of previous literature research.

Table 1 - Brief literature review

\begin{tabular}{||l|l|c|c||}
\hline Year & \multicolumn{1}{|c|}{ Authors } & $\begin{array}{c}\text { No. of } \\
\text { samples }\end{array}$ & $\begin{array}{c}\text { Coefficient of } \\
\text { determination } \\
\mathrm{R}^{2}\end{array}$ \\
\hline \hline 1992 & Black et al. [9] & 5,722 & $0.20-0.50$ \\
\hline 2001 & Kirk et al. [10] & 137 & $0.04-0.14$ \\
\hline 2002 & $\begin{array}{l}\text { Bischoff and } \\
\text { Bullock [11] }\end{array}$ & 1,341 & $0.0152-0.3236$ \\
\hline 2002 & Wolshon et al. [12] & 237 & Unavailable \\
\hline 2006 & Rasdorf et al. [13] & 1,047 & $0.0103-0.4811$ \\
\hline 2009 & Kipp and Fitch [14] & 398 & $0.0266-0.1304$ \\
\hline 2011 & Carlson et al. [15] & 1,385 & $0.10-0.20$ \\
\hline 2014 & $\begin{array}{l}\text { Pike and Carlson } \\
\text { [16] }\end{array}$ & 525 & 0.4436 \\
\hline
\end{tabular}

Although most of the studies had sufficient statistical data, in most cases the developed models had relatively poor accuracy (Table 1 ). The stated lack of accuracy shows the necessity to conduct further research aimed at developing more accurate prediction models for the functional service life of traffic signs, which could be effectively used for the optimization of traffic sign maintenance system.

Upon reviewing the previous research, the authors Pike and Carlson [16] as well as Brimley and Carlson [18] found that the limitations of the past studies included the following: sign sheeting materials changing over time (new materials released, changes to current materials), age distribution of in-service signs, signs with poor retroreflection being replaced and thus not being included in degradation modelling, not accounting for initial retroreflection of signs, and signage being the only consistent factor found to influence degradation.

The traffic signs analysed in the research presented in this paper overcome the shortcomings emphasized in [16] and [18]. This fact leads to a better accuracy of the developed models.

\section{DATA COLLECTION METHODOLOGY}

The Department for Traffic Signalization at the Faculty of Transport and Traffic Sciences, University of Zagreb collected the data used in this research in the City of Zagreb area (Republic of Croatia) in the period from 2008 to 2016. The collected data relate to the coefficient of retroreflection of the retroreflective material of Classes I, II (white, red, and blue colour) and III (red and yellow). The coefficient of retroreflection, RA, is the coefficient of luminous intensity of a plane retroreflection surface to its area or as a ratio of returned intensity to incident illumination divided by the area of the retroreflection. The metric unit for retroreflection coefficient is $\mathrm{cd} / \mathrm{Ix} / \mathrm{m}^{2}$ [19].

According to the relevant Croatian regulations, the most commonly used signs are those made of Class I materials. Only several traffic signs (stop signs, warning for pedestrians, etc.) must be manufactured from Class II and Class III materials. Consequently, the most analysed signs in this research are made of Class I, then Class II and Class III materials (Figure 1).

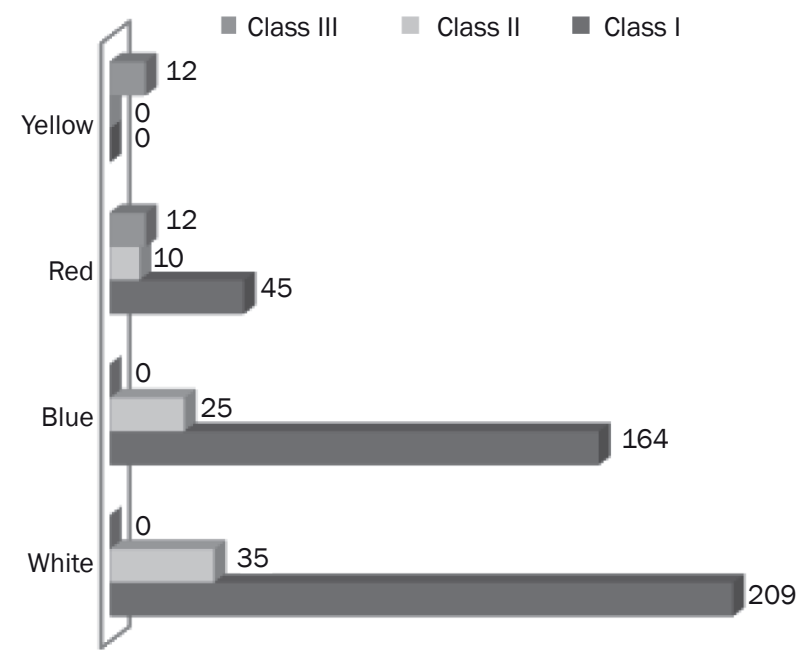

Figure 1 - The number of analysed traffic signs with different colours (Class I, II, III)

The retroreflection coefficient of traffic signs can be measured by using the static or the dynamic method. The static method involves the use of handheld retroreflectometers, while the dynamic one includes using a vehicle-mounted device and retroreflection measurements taken while driving. As previously stated, Carlson et al. [15] conducted a test of measurement accuracy by using the dynamic method and found that the dynamic system failed to measure sign retroreflection accurately and could result in waste to agencies removing signs that are still meeting minimum retroreflection requirements.

The authors in this research used a handheld retroreflectometer Zehntner ZRS 6060. The geometry of this instrument corresponds to the values of the European Standard (EN 12899-1: Fixed, Vertical Road Traffic Signs - Part 1: Permanent Signs) which implies an observation angle $(\alpha)$ of $0.33^{\circ}$ and an entrance angle $(\beta 1)$ of $5^{\circ}$. As described in [20] the position of the sign at the side of the road and the geometry of an oncoming vehicle position primarily determine the entrance angle that is formed between the light rays falling on the surface of the sign and the line that goes vertically from the surface. The observation angle is the angle between the incoming light ray and the reflected ray. 
Figure 2 shows the entrance and observation angles.
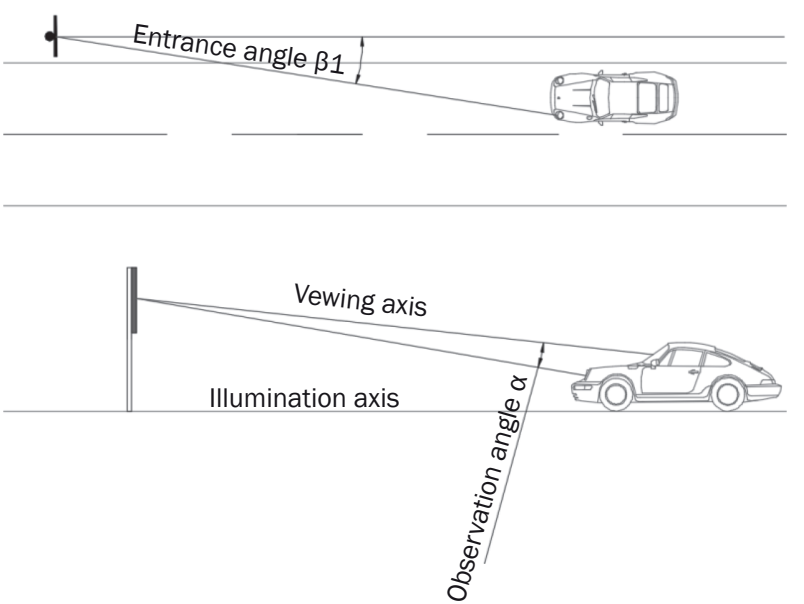

Figure 2 - Entrance and observation angles for a traffic sign

Source: Adapted by authors according to [19]

According to EN 12899-1, the minimum coefficient of retroreflection RA $\left(\mathrm{cd} / \mathrm{Ix} / \mathrm{m}^{2}\right)$ of traffic signs must match the values shown in Table 2, Table 3 and Table 4. The coefficient of retroreflection $\left(R_{A}\right)$ of all printed colours, except white, shall not be less than $70 \%$ of the values shown in these tables. In case any of the colours on the sign do not meet the minimum prescribed value, the sign must be replaced with a new one.

When measuring retroreflection, the authors measured each particular sign and each colour on the sign four times in different areas of the sign. The relevant value of retroreflection for a specific colour of a sign represents the average values of all four measurements of that colour.

All the signs comprised in the present research have been made of a retroreflective material of the same manufacturer and were installed on the road as new in $\mathbf{2 0 0 8}$ when the research started. The signs retroreflection was measured for the first time upon installation (in 2008) to determine their initial retroreflection. Since then, the same signs underwent identical tests each year up to 2016. Before each measurement, the traffic signs were cleaned to ensure proper retroreflection as the study conducted by Wolshon et al. in [12] showed that the average increase in retroreflection after cleaning the traffic signs is about 33\%.

\section{RESULTS AND DISCUSSION}

This section will present the results of the conducted analysis, and models for predicting the functional service life of particular traffic sign colours and classes of material. As previously stated, each colour was measured four times, and the average value of these measurements is the relevant value for a
Table 2 - Retroreflection coefficient $R_{A}$ : Class I (cd/Ix/ $\left.\mathrm{m}^{2}\right)$

\begin{tabular}{|c|c|c|c|c|c||}
\hline \multicolumn{2}{|c|}{$\begin{array}{c}\text { Geometry of } \\
\text { measurements }\end{array}$} & \multicolumn{5}{|c||}{ Colour } \\
\hline \multirow{2}{*}{$\alpha$} & $\begin{array}{c}\beta 1 \\
\left(\beta_{2}=0\right)\end{array}$ & White & Yellow & Red & Blue \\
\hline \hline \multirow{3}{*}{$0.2^{\circ}$} & $+5^{\circ}$ & 70 & 50 & 14.5 & 4 \\
\cline { 2 - 6 } & $+30^{\circ}$ & 30 & 22 & 6 & 1.7 \\
\cline { 2 - 6 } & $+40^{\circ}$ & 10 & 7 & 2 & 0.5 \\
\hline \multirow{3}{*}{$0.33^{\circ}$} & $+5^{\circ}$ & 50 & 35 & 10 & 2 \\
\cline { 2 - 6 } & $+30^{\circ}$ & 24 & 16 & 4 & 1 \\
\cline { 2 - 6 } & $+40^{\circ}$ & 9 & 6 & 1.8 & $\#$ \\
\hline \multirow{3}{*}{$2^{\circ}$} & $+5^{\circ}$ & 5 & 3 & 1 & $\#$ \\
\cline { 2 - 6 } & $+30^{\circ}$ & 2.5 & 1.5 & 0.5 & $\#$ \\
\cline { 2 - 6 } & $+40^{\circ}$ & 1.5 & 1.0 & 0.5 & $\#$ \\
\hline \multirow{2}{*}{$\#-$ value greater than zero but not significant or applicable } \\
\hline \hline
\end{tabular}

Source: [19]

Table 3 - Retroreflection coefficient $R_{A}$ : Class II (cd/lx/m²)

\begin{tabular}{|c|c|c|c|c|c||}
\hline \hline \multicolumn{2}{||c|}{$\begin{array}{c}\text { Geometry of } \\
\text { measurements }\end{array}$} & \multicolumn{4}{|c||}{ Colour } \\
\hline \multirow{2}{*}{$\alpha$} & $\begin{array}{c}\beta 1 \\
\left(\beta_{2}=0\right)\end{array}$ & White & Yellow & Red & Blue \\
\hline \hline \multirow{3}{*}{$0.2^{\circ}$} & $+5^{\circ}$ & 250 & 170 & 45 & 20 \\
\cline { 2 - 6 } & $+30^{\circ}$ & 150 & 100 & 25 & 11 \\
\cline { 2 - 6 } & $+40^{\circ}$ & 110 & 70 & 15 & 8 \\
\hline \multirow{3}{*}{$0.33^{\circ}$} & $+5^{\circ}$ & 180 & 120 & 25 & 14 \\
\cline { 2 - 6 } & $+30^{\circ}$ & 100 & 70 & 14 & 8 \\
\cline { 2 - 6 } & $+40^{\circ}$ & 95 & 60 & 13 & 7 \\
\hline \multirow{3}{*}{$2^{\circ}$} & $+5^{\circ}$ & 5 & 3 & 1 & 0.2 \\
\cline { 2 - 6 } & $+30^{\circ}$ & 2.5 & 1.5 & 0.4 & $\#$ \\
\cline { 2 - 6 } & $+40^{\circ}$ & 1.5 & 1.0 & 0.3 & $\#$ \\
\hline \multirow{2}{*}{ - value greater than zero but not significant or applicable } \\
\hline
\end{tabular}

Source: [19]

Table 4 - Retroreflection coefficient RA: Class III (cd/Ix/m²)

\begin{tabular}{|c|c|c|c|c|c|}
\hline \multicolumn{2}{|c|}{$\begin{array}{c}\text { Geometry of } \\
\text { measurements }\end{array}$} & \multicolumn{4}{|c|}{ Colour } \\
\hline$\alpha$ & $\begin{array}{c}\beta 1 \\
\left(\beta_{2}=0\right)\end{array}$ & White & Yellow & Red & Blue \\
\hline \multirow{3}{*}{$0.1^{\circ}$} & $+5^{\circ}$ & 850 & 550 & 170 & 55 \\
\hline & $+20^{\circ}$ & 600 & 390 & 120 & 40 \\
\hline & $+30^{\circ}$ & 425 & 275 & 85 & 28 \\
\hline \multirow{3}{*}{$0.2^{\circ}$} & $+5^{\circ}$ & 625 & 400 & 125 & 40 \\
\hline & $+20^{\circ}$ & 450 & 290 & 90 & 30 \\
\hline & $+30^{\circ}$ & 325 & 210 & 65 & 20 \\
\hline \multirow{3}{*}{$0.33^{\circ}$} & $+5^{\circ}$ & 425 & 275 & 85 & 28 \\
\hline & $+20^{\circ}$ & 300 & 195 & 60 & 20 \\
\hline & $+30^{\circ}$ & 225 & 145 & 45 & 15 \\
\hline
\end{tabular}

Source: [21] 
certain colour on a sign. For instance, Class I white colour included 836 measurements (four measurements per sign). The relevant value used as an input for the model is the average value of those four measurements. Therefore, there were 209 relative values obtained for white colour for Class I.

If the relevant values of all the colours on a certain sign exceed the minimum prescribed values for a certain class (Tables 3, 4 and 5), then the sign meets the requirements. If one or more relevant colour values of a certain sign are below the minimum prescribed values, then the sign does not comply with the requirements, and it needs to be replaced. The observed data show that the red colour is the most "time sensitive" colour, i.e. it is the first one that is non-compliant according to the requirements (Figure 3 ). Research done by Brimley et al. [22] presented a similar conclusion.

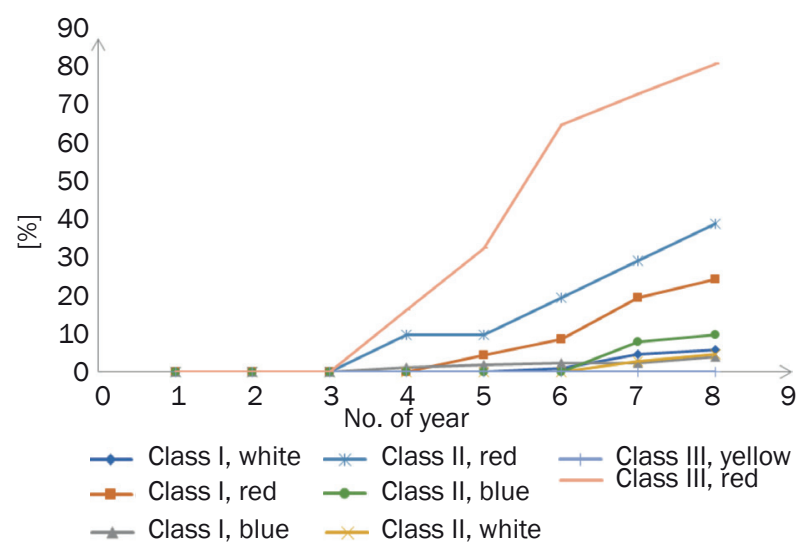

Figure 3 - The percentage of non-compliant traffic signs per time by traffic sign class and colour

Based on the data analysis, the authors obtained the models for predicting the functional service life of traffic signs for each colour and class of retroreflective material, where the retroreflection degradation was described as the function of time, i.e. signage.
The literature review showed that the linear models proved to be the best fit for predicting the retroreflection degradation of traffic signs [18]. This study also confirmed the fit, but the logarithmic and exponential regression show very similar accuracy.

The analysis and model development were made in SPSS software. Each group of data (class and colour group data) is normally distributed. The assessment of the normal probability plots (Q-Q plot) also confirmed the normal distribution. In this plot, the observed data for each score is plotted against the expected value from the normal distribution, and a reasonably straight line suggests a normal distribution.

The modelling of retroreflection degradation was done with regression analysis. For each Class and colour of material, linear, logarithmic and exponential regression was done. As this study was conducted only in the area of the City of Zagreb different independent variables such as precipitation, temperature differences, solar radiation etc. were not considered and the retroreflection degradation was modelled only as a function of sign age. The coefficient of determination $\mathrm{R}^{2}$ varied from 0.383 to 0.783 depending on the Class and colour of material. Linear and exponential models show the best accuracy with the average $\mathrm{R}^{2} 0.57$ for linear and 0.56 for exponential model. Also, the average Pearson correlation for Class I material is -0.707 , for Class II -0.792 and Class III -0.760 which proves that there is a strong negative correlation between retroreflection and age of the sign, meaning that with the increase of sign age the retroreflection will decrease.

Overall, the presented models show good accuracy and significant improvement compared to the existing models mentioned in the literature review.

Table 5 shows the results, whereas $R_{A}$ is the retroreflection value at a given moment, and $t$ is the traffic sign age expressed in years.

Table 5 - Final obtained results for Classes I, II or III and different colours of traffic signs

\begin{tabular}{|c|c|c|c|c|c|c|}
\hline Class I & \multicolumn{2}{|r|}{ White $(n=209)$} & \multicolumn{2}{|r|}{ Red $(n=45)$} & \multicolumn{2}{|r|}{ Blue $(n=164)$} \\
\hline Equation & $\mathrm{R}^{2}$ & Function & $\mathrm{R}^{2}$ & Function & $\mathrm{R}^{2}$ & Function \\
\hline $\begin{array}{l}\text { Lin } \\
\text { Log } \\
\text { Exp }\end{array}$ & $\begin{array}{l}0.567 \\
0.522 \\
0.568\end{array}$ & $\begin{array}{l}R_{A}=83.905-3.121 t \\
R_{A}=83.684-10.428 \log (\mathrm{t}) \\
R_{A}=84.684 \cdot \exp (-0.045 \mathrm{t})\end{array}$ & $\begin{array}{l}0.452 \\
0.383 \\
0.474\end{array}$ & $\begin{array}{l}R_{A}=14.565-0.789 \mathrm{t} \\
R_{A}=14.366-2.526 \log (\mathrm{t}) \\
R_{A}=15.007 \cdot \exp (-0.075 \mathrm{t})\end{array}$ & $\begin{array}{l}0.484 \\
0.434 \\
0.437\end{array}$ & $\begin{array}{l}R_{A}=3.999-0.225 t \\
R_{A}=3.969-0.742 \log (\mathrm{t}) \\
R_{A}=4.106 \cdot \exp (-0.078 \mathrm{t})\end{array}$ \\
\hline Class II & & White $(n=35)$ & & $\operatorname{Red}(n=10)$ & & Blue $(n=25)$ \\
\hline Equation & $\mathrm{R}^{2}$ & Function & $\mathrm{R}^{2}$ & Function & $\mathrm{R}^{2}$ & Function \\
\hline $\begin{array}{l}\text { Lin } \\
\text { Log } \\
\text { Exp }\end{array}$ & $\begin{array}{l}0.600 \\
0.547 \\
0.600\end{array}$ & $\begin{array}{l}R_{A}=231.454-4.988 \mathrm{t} \\
R_{A}=231.002-16.590 \log (\mathrm{t}) \\
R_{A}=232.106 \cdot \exp (-0.024 \mathrm{t})\end{array}$ & $\begin{array}{l}0.516 \\
0.496 \\
0.474\end{array}$ & $\begin{array}{l}R_{A}=39.935-2.603 t \\
R_{A}=40.000-8.887 \log (\mathrm{t}) \\
R_{A}=42.131 \cdot \exp (-0.100 \mathrm{t})\end{array}$ & $\begin{array}{l}0.781 \\
0.724 \\
0.783\end{array}$ & $\begin{array}{l}R_{A}=28.228-2.083 \mathrm{t} \\
R_{A}=28.111-6.984 \log (\mathrm{t}) \\
R_{A}=30.330 \cdot \exp (-0.115 \mathrm{t})\end{array}$ \\
\hline Class III & & Yellow $(n=12)$ & & $\operatorname{Red}(n=12)$ & & \\
\hline Equation & $\mathrm{R}^{2}$ & Function & $\mathrm{R}^{2}$ & Function & & \\
\hline $\begin{array}{l}\text { Lin } \\
\text { Log } \\
\text { Exp }\end{array}$ & $\begin{array}{l}0.511 \\
0.460 \\
0.518\end{array}$ & $\begin{array}{l}R_{A}=524.401-10.150 t \\
R_{A}=523.147-33.512 \log (\mathrm{t}) \\
R_{A}=525.411 \cdot \exp (-0.021 \mathrm{t})\end{array}$ & $\begin{array}{l}0.649 \\
0.584 \\
0.643\end{array}$ & $\begin{array}{l}R_{A}=149.139-9.292 \mathrm{t} \\
R_{A}=148.013-30.695 \log (\mathrm{t}) \\
R_{A}=156.471 \cdot \exp (-0.091 \mathrm{t})\end{array}$ & & \\
\hline
\end{tabular}




\section{Survival analysis}

Figure 4 presents the probability of traffic sign survival in the considered time horizon. The probability of survival has been calculated as follows:

The probability of survival $=($ Total No. of Signs $-\mathrm{Cu}$ mulative Number of Non-Compliant Signs in Considered Year)/(Total No. of Signs - Cumulative Number of Non-Compliant Signs in Previous Year)

In the considered case study, Total No. of Signs is 509 . The probability of survival $=(509-10) /(509-5)=$ $99 \%$.

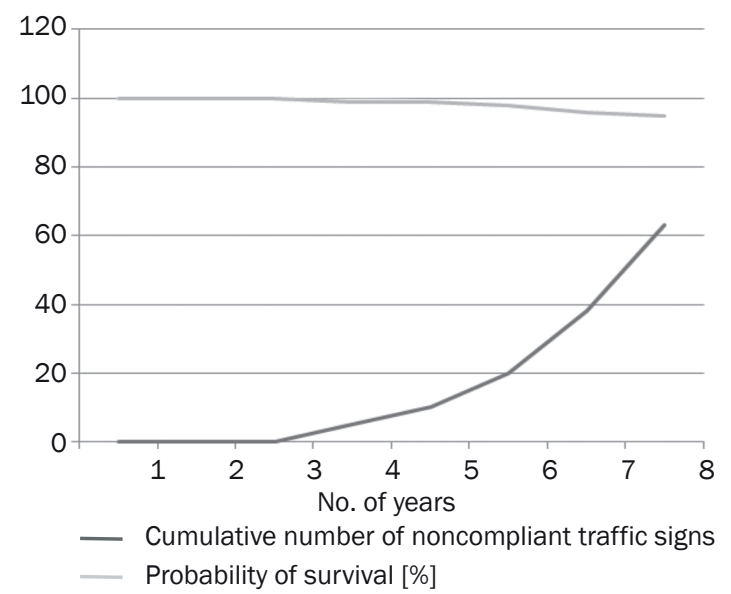

Figure 4 - Probability of traffic sign survival

The survival curve shows the probability of surviving, i.e. the probability that a traffic sign has satisfactory retroreflection - good visibility. Based on Figure 4, it can be concluded that a traffic sign has about 95\% probability to have a satisfactory retroreflection after eight years. This conclusion is in accordance with [22].

\section{CONCLUSION}

The functional service life of traffic signs was the subject of several scientific and professional types of research. The aim of this research was to gain knowledge on how traffic sign retroreflection degrades over time. Creating a model for predicting the functional service life of traffic signs is a vital part of developing a comprehensive sign maintenance program. Previous studies have resulted in developing some models for different colours and classes of retroreflective material used to make traffic signs. Even though most of the studies had sufficient statistical data, in most cases the developed models had a relatively poor accuracy. Moreover, previous research had certain limitations such as: sign sheeting materials changing over time (new materials launched, changes to current materials), age distribution of in-service signs, signs with poor retroreflection being replaced and thus not being included in degradation modelling, not accounting for initial retroreflection of signs etc. The emphasized drawbacks limit the practical application of the developed models in the system for traffic sign maintenance.

The presented research included the traffic signs in the City of Zagreb. All the considered signs were produced by the same manufacturer and installed on the road at the same time, in 2008 . The authors measured the retroreflection of these signs in the period from 2008 to 2016.

Based on the collected data, the authors developed models to predict the functional service life of particular colours and materials of traffic signs. The presented models showed good accuracy and the average coefficient of determination for all linear models is $0.57,0.52$ for all logarithmic models, and 0.56 for all exponential models.

Benefits derived from the obtained models are primarily intended for road authorities that may use them to forecast when the retroreflection of traffic signs will drop below minimal prescribed values and, according to that, plan the maintenance activities. Proper maintenance, i.e. timely changed signs may positively affect the drivers and increase traffic safety. Overall, models present an efficient tool for planning, organization and optimization of traffic sign maintenance system and make a significant contribution, both in scientific and practical terms.

The presented study has certain limitations, such as: data collection in only one area, which cannot show the influence of environmental conditions; developed model use the age of the signs as the only input; some of the samples have small sizes, which can affect the obtained results.

Because of the mentioned limitations the applicability of the models in other countries may vary depending on the environmental conditions. In the course of normal wear, retroreflection of traffic signs may be affected by environmental conditions such as sunlight, temperature, dust, and moisture, as well as sign direction and position. Although the existing literature $[9,11,12]$ suggests that there is no direct correlation between the named factors and retroreflection degradation further detailed research is needed. For these purposes, it is suggested to conduct a research aimed at determining and "weighing" the influence of certain factors on the degradation of traffic sign retroreflection. In addition, measurements of the tested signs will continue in the coming years and the named limitations will be considered in the authors' future research, with the aim of checking the robustness of the obtained results.

DARIO BABIĆ, mag. ing. traff. ${ }^{1}$

E-mail: dario.babic@fpz.hr

Doc. dr. Sc. DARKO BABIĆ ${ }^{1}$

E-mail: darko.babic@fpz.hr

Izv. prof. dr. Sc. DRAGANA MACURA ${ }^{2}$

E-mail: d.macura@sf.bg.ac.rs

${ }^{1}$ Sveučilište u Zagrebu, Fakultet prometnih znanosti

Vukelićeva 4, 10000 Zagreb, Hrvatska

2 Univerzitet u Beogradu, Saobraćajni fakultet

Vojvode Stepe 305, Beograd, Srbija 


\section{MODEL ZA PREDVIĐANJE FUNKCIONALNOG VIJEKA PROMETNIH ZNAKOVA - ANALIZA SLUČAJA U REPUBLICI HRVATSKOJ}

\section{SAŽETAK}

Prometni znakovi predstavljaju osnovne elemente komunikacije između nadležnih cestovnih vlasti i sudionika u prometu te kao takvi upravljaju, reguliraju, informiraju te upozoravaju sudionike u prometu s ciljem osiguravanja njihovog sigurnog kretanja prometnim mrežama. Da bi prometni znakovi ispunjavali svoju funkciju oni moraju biti pravovremeno vidljivi svim sudionicima u prometu u svim vremenskim i prometnim uvjetima, odnosno moraju imati zadovoljavajuća retroreflektirajuća svojstva. Ovaj rad predstavlja istraživanje degradacije retrorefleksije prometnih znakova. Cilj rada je razviti modele kojima će se efikasno moći predvidjeti retrorefleksija prometnih znakova te na taj način optimizirati aktivnosti održavanja i zamijene prometnih znakova, sve u cilju povećanja prometne sigurnosti. Istraživanje je obuhvatilo mjerenja retrorefleksije retroreflektirajućih materijala klase I i II (bijele, crvene i plave boje) te klase III (crvene i žute boje). Na temelju prikupljenih podataka na području Grada Zagreba (Republika Hrvatska), razvijeni su modeli za predviđanje funkcionalnog vijeka pojedinih boja i materijala za iz radu prometnih znakova. S obzirom da prosječni koeficijent determinacije razvijenih modela iznosi između 0,55 i 0,60, modeli predstavljaju efikasan alat u sustavu održavanja prometnih znakova.

\section{KLUČNE RIJEČI}

prometni znakovi; retrorefleksija; degradacija prometnih znakova; funkcionalni vijek;

\section{REFERENCES}

[1] Traynor TL. The relationship between regional economic conditions and the severity of traffic crashes. Traffic Injury Prevention. 2009;10(4):368-74. doi: 10.1080/15389580902995174

[2] Jamson SL, Tate FN, Jamson AH. Evaluating the effects of bilingual traffic signs on driver performance and safety. Ergonomics. 2005;48(15):1734-1748. doi: 10.1080/00140130500142191

[3] Pašagić S, Pašagić J, Ščukanec A. Influence of driver's experience on textual traffic sign efficiency depending on visibility. Scientific Journal on Traffic and Transportation Research. 2000 May;12(3):109-114.

[4] Practices to manage traffic sign retroreflectivity: A synthesis of highway practice. NCHRP Synthesis 431. Washington D.C.: Transportation Research Board; 2012. p. 44.

[5] Bible RC, Johnson N. Retroreflective material specifications and on-road sign performance. Transportation Research Record. 2002;1801:61-72. doi:10.3141/180108

[6] Carlson PJ, Hawkins HG. Updated minimum retroreflectivity levels for traffic signs. Report No. FHWARD-03-81. Washington, D.C.: U.S. Department of Transportation, Federal Highway Administration; 2004.

[7] Zwahlen HT, Russ A, Vatan S. Field evaluation of unlighted overhead guide signs using older drivers. Report No. FHWA/OH-2003/015. Athens, OH: Ohio University; 2003.

[8] Carlson PJ, Holick A. Maximizing legibility of unlit freeway guide signs with clearview font and combinations of retroreflective sheeting materials. Transportation Research Record. 2005;1918:26-34. doi:10.3141/1918-04

[9] Black KL, McGee HW, Hussain SF, Rennilson JJ. Service life of retroreflective signs. Report No. FHWARD-90-101. Washington, D.C.: U.S. Department of Transportation, Federal Highway Administration; 1992.

[10] Kirk AR, Hunt EA, Brooks EW. Factors affecting sign retroreflectivity. Publication OR-RD-01-09. Salem, OR: Oregon Department of Transportation; 2001.

[11] Bischoff AL, Bullock DM. Sign retroreflectivity study. Report No. FHWA/IN/JTRP-2002/22. Indianapolis, IN: Indiana Department of Transportation; 2002.

[12] Wolshon B, Degeyter R, Swargam J. Analysis and predictive modelling of road sign retroreflectivity performance. Paper presented at: The 16th Biennial Symposium on Visibility and Simulation; 2002 June 2-4; Iowa City, USA.

[13] Rasdorf WJ, Hummer JE, Harris EA, Immaneni VPK, Yeom C. Designing an efficient nighttime sign inspection procedure to ensure motorist safety. Report FHWA/NC/2006-08. Raleigh, NC: North Carolina Department of Transportation; 2006.

[14] Kipp WME, Fitch JMV. Evaluation of measuring methods for traffic sign retroreflectivity. Report 2009-8. Montpelier, VT: Vermont Agency of Transportation; 2009.

[15] Carlson PJ, Higgins L, Ré J. Research and recommendations for a statewide sign retroreflectivity maintenance program. Report FHWA/TX-12/0-6408-1. Austin, TX: Texas Department of Transportation; 2011.

[16] Pike AM, Carlson PJ. Evaluation of sign sheeting service life in Wyoming. Paper presented at: The Transportation Research Board 93rd Annual Meeting; 2014 January 12-16; Washington D.C., USA.

[17] Preston H, Atkins KC, Lebens M, Jensen M. Traffic sign life expectancy. Report 2014-20. Minnesota Department of Transportation; 2014.

[18] Brimley B, Carlson P. The current state of research on the long-term deterioration of traffic signs. Paper No. 13-0033. Washington D.C.: Transportation Research Board; 2013.

[19] European Committee for Standardization. Fixed, vertical road traffic signs - Part 1: Permanent signs. EN 12899-1; 2008.

[20] Scukanec A, Babic D, Sokol, H. Methodology for Measuring Traffic Signs Retroreflection. European Scientific Journal, Special Edition. 2014;3:135-142.

[21] Consiglio nazionale delle ricerche. Common understanding of assessment procedure (CUAP): Microprismatic retro-reflective sheetings; 2002.

[22] Brimley B, Hawkins HG, Carlson P. Analysis of retroreflectivity and colour degradation in sign sheeting. Presented at: Transportation Research Board 90 ${ }^{\text {th }}$ Annual Meeting; 2011. 